\title{
DISERTACIONES
}

ENSAYOS

Para citar este artigo: Resende Quadros, A.,Montuori Fernandes, C., \& De Oliveira, L. A.(2021). A "revanche" e "os perversos": como Eliane Brum aborda Jair Bolsonaro em sua eleição e nos seus 100 primeiros dias de governo. Anuario Electrónico de Estudios en Comunicación Social “Disertaciones”,14(1), 1-18. https://doi. org/10.12804/revistas.urosario.edu.co/disertaciones/a.8555

\section{A "REVANCHE" E "OS PERVERSOS": COMO ELIANE BRUM ABORDA JAIR BOLSONARO EM SUA ELEIÇÃO E NOS SEUS 100 PRIMEIROS DIAS DE GOVERNO}

The "Rematch"and "the Wicked": How Eliane Brum Addressed Jair Bolsonaro's Election and his First 100 Days of Government

La "revancha" y "los malvados": cómo Eliane Brum aborda a Jair Bolsonaro en su elección y en sus primeros 100 días de gobierno

Ana Resende Quadros, Universidade Federal de Juiz de Fora (Brasil)

anarquadros@gmail.com

Carla Montuori Fernandes, Universidade Paulista (Brasil)

carla_montuori@ig.com.br

Luiz Ademir de Oliveira, Universidade Federal de Juiz de Fora (Brasil)

luizoli@ufsj.edu.br

Recebido: 11 de dezembro de 2019

Aprovado: 31 de outubro de 2020

Fecha de prepublicación: 16 de dezembro de 2020 


\section{DISERTACIONES}

ENSAYOS

\section{RESUMO}

Este artigo analisa de que forma a jornalista e escritora Eliane Brum abordou a eleição de Jair Bolsonaro, em 2018, e os primeiros 100 dias de seu governo, a partir dos artigos a "A revanche dos ressentidos" e "Cem dias sob o domínio dos perversos". O percurso do trabalho se constituiu em avaliar de que forma Brum empregou suas estratégias de destaque ao desacontecimento, ou seja, de acontecimentos cotidianos e buscou responder como a narrativa foi construída, tendo em vista que se tratava de um tema tipicamente noticioso, fortemente vinculado aos padrões hegemônicos de noticiabilidade. Para tanto, foi feita uma análise de conteúdo seguindo os princípios de Bardin (2011) delimitando a análise nas seguintes categorias: uso do acontecimento e do desacontecimento em seus textos, o enquadramento empregado e a construção da imagem de seus personagens. $O$ que se viu nas temáticas abordadas pela jornalista foi uma aproximação ao recurso do acontecimento, ainda que os textos remetessem à aspectos do jornalismo literário.

Palavras-chave: acontecimento; desacontecimento; Eliane Brum; Jair Bolsonaro; eleições.

\section{ABSTRACT}

This article assesses how journalist and writer Eliane Brum addressed Jair Bolsonaro's election in 2018as well as his first 100 days of government, according to the articles "The revenge of the resentful" ("La venganza de los resentidos") and "100 days under the sway of the evil" ("Cien días bajo el dominio de los malvados"). The research evaluates how Brum used her strategies to highlight the lack of events, that is, daily occurrences and sought to respond to the method that was being used to build the narrative, considering that this typically informative topic is closely related to hegemonic broadcast patterns. To this end, a content analysis was performed in accordance to Bardin (2011) with the following categories: the use of the event and the lack of event in her texts, the adopted framework, and the construction of the characters' image. Although texts concerned the aspects of literary journalism, the topics addressed by the journalist constitute an approach of event resource.

Keywords: Event; disappointment; Eliane Brum; Jair Bolsonaro; elections.

\section{RESUMEN}

Este artículo analiza cómo la periodista y escritora Eliane Brum abordó la elección de Jair Bolsonaro en 2018, y los primeros 100 días de su gobierno, a partir de los artículos "La venganza de los resentidos" y "Cien días bajo el dominio de los malvados”. El curso del trabajo consistió en evaluar cómo Brum utilizó sus estrategias para resaltar la falta de acontecimiento, es decir, de hechos cotidianos, y buscó dar respuesta a cómo se construyó la narrativa, considerando que se trataba de un tema típicamente informativo, fuertemente ligado a patrones hegemónicos de noticias. Para ello, se realizó un análisis de contenido siguiendo los principios de Bardin (2011), delimitando el análisis en las siguientes categorías: uso del evento y la falta de evento en sus textos, el marco empleado y la 


\section{DISERTACIONES}

ENSAYOS

Tecnologías y métodos computacionales para la investigación en ciencias sociales y comunicación

ISSN: 1856-9536

Doi: https://doi.org/10.12804/revistas.urosario.edu.co/disertaciones/a.8555

Volumen 14, Número 1 / Enero-junio 2021

Versión PDF para imprimir desde

http://revistas.urosario.edu.co/index.php/disertaciones

construcción de la imagen de sus personajes. Lo que se vio en los temas abordados por el periodista fue una aproximación al recurso del evento, aunque los textos se referían a aspectos del periodismo literario.

Palabras clave: evento; decepción; Eliane Brum; Jair Bolsonaro; elecciones.

O meio político brasileiro encontra-se em uma grave crise institucional, que emergiu a partir das Jornadas de 2013, quando uma parcela da população, dita apartidária, foi para as ruas protestar contra a corrupção. Desde então, o governo da presidente Dilma Rousseff (PT) sofreu uma queda de popularidade significativa. Em 2014, teve início a Operação Lava Jato, que culminou na prisão de dezenas de lideranças políticas, principalmente do PTe do MDB, e de empresários, acusados de corrupção e recebimento de propinas em contratos em especial da Petrobras.

As eleições de 2014 já mostraram um país com forte polarização, descrença nas instituições políticas e o prenúncio de uma forte crise econômica, que culminou no aumento expressivo do desemprego. Neste clima que Dilma venceu a eleição contra Aécio Neves numa das disputas mais acirradas desde a redemocratização. Dilma Rousseff foi deposta da Presidência da República em 31 de agosto de 2016, quando houve a votação final no Senado sobre o pedido de impeachment contra a petista. Souza (2016) e Santos (2017) classificam o impeachment de Dilma como um golpe jurídico, político, midiático e econômico, tendo em vista a confluência das elites que sempre governaram o país.

Com a prisão de Lula, em abril de 2018, o cenário da eleição presidencial de 2018 ficou ainda mais instável. Com a candidatura do ex-presidente impedida, o PTo substituiu por Fernando Haddad em setembro. O PSDB, que até então havia sido o maior rival político do PT,encontrou dificuldades de angariar votos para seu candidato: Geraldo Alckmin, também investigado por corrupção. Marina Silva (REDE), terceira colocada nas eleições de 2014, terminou a disputa de 2018 com menos de $1 \%$ dos votos.

Considerado uma figura excêntrica e sem chances de se eleger presidente, o contexto político favoreceu para que Bolsonaro (PSL) surpreendesse e vencesse a eleição, mesmo sem ter uma frente partidária de apoio. Com menos de um ano de governo, o presidente enfrentou múltiplas crises. A sua última polêmica que fez com que sua popularidade caísse foi a ocorrência de muitos focos de incêndio na Amazônia, chamando a atenção de ongs e de países europeus preocupados com a questão ambiental. Bolsonaro tentou relativizar, mas a repercussão foi muito negativa, principalmente depois de declarações polêmicas contra líderes mundiais, como o presidente da França, Emmanuel Macron. Além disso, o presidente é acusado de se envolver mais em uma campanha permanente do que no governo do País, acirrando a tensão entre os brasileiros. Se, a seu tempo, a 


\section{DISERTACIONES}

ENSAYOS

campanha entre Dilma e Aécio pareceu despertar inimizades entre os apoiadores de cada um, a campanha de 2018 provou que a disputa poderia se aprofundar ainda mais.

Num levantamento feito pela Agência Pública, entre 30 de setembro e 10 de outubro de 2018, ao menos 50 agressões foram cometidas por eleitores de Bolsonaro (Maciel et al., 2018). Isso mostra que, apesar de passada a eleição, o país continua polarizado e com um forte discurso de ódio, seja por defensores de Bolsonaro ou pela forte oposição. Como o presidente usa recorrentemente as mídias sociais, em especial o Twitter, para não ter que acionar a mídia tradicional, tem sido na internet os principais embates de seus aliados e críticos.

Dadas estas circunstâncias e as teorias construcionistas que, como explica Traquina (2001), acreditam que as notícias são construídas pelos processos entre agentes sociais e fontes, além de como os jornalistas narram os fatos e as maneiras de interpretá-los por parte do receptor. Ademais, como afirma Lima (2004), a própria mídia é um ator político, considera-se relevante avaliar como figuras midiáticas importantes relataram as eleições de Dilma Rousseff (2014) e de Jair Bolsonaro (2018).

Neste ambiente midiático, alguns colunistas dedicam-se às críticas mais contundentes ao presidente. Para este estudo, foi escolhida a jornalista Eliane Brum. Desde 2013, ela escreve colunas quinzenais para o jornal global El País, com textos traduzidos para o espanhol e compartilhados nas versões do jornal para a Europa e para o restante da América.

Em seus primeiros textos após as eleições tanto de 2014 quanto de 2018, a jornalista dedicou sua coluna aos temas. Neste artigo, foram analisados os textos "A revanche dos ressentidos" (06/11/18) e "Cem dias sob o domínio dos perversos" (12/04/2019), visando a comparar as abordagens da jornalista por meio de uma análise de conteúdo nos moldes propostos por Bardin (2011).

\section{Da centralidade da mídia aos processos de midiatização}

A mídia desempenha um papel central na nossa sociedade, permeando os diferentes campos simbólicos. Rodrigues (1990) afirma que a instância comunicativa midiática passa a ser mediadora da vida social. Intermediando os outros campos sociais, o discurso midiático assume uma natureza exotérica, que se constrói um discurso de fácil compreensão dos repertórios dos demais campos simbólicos.

De todas as áreas que fazem uso da mediação para transmitir seus discursos, talvez a política seja a que mais dependa da mídia para atingir seus objetivos. Thompson (2013) explica que o surgimento da mídia eletrônica nos possibilitou um maior acesso à imagem de líderes políticos e celebridades do que se tinha antes. Muitas vezes somos capazes de nos sentirmos íntimos de pessoas que nunca encontraremos em nossas vidas cotidianas. Essa evolução tecnológica modificou as formas de poder e, também, a maneira como distinguimos o público e o privado.

Os políticos sempre controlaram sua visibilidade. Porém, essa antiga prática se tornou mais difícil nos tempos modernos. Antes, suas interações eram basicamente com os membros da corte, salvo grandes eventos como coroações, marchas de vitórias e funerais. Nesses eventos maiores, onde interagiam com o público, conseguiam se colocar metafórica e literalmente acima e distante de todos, mantendo o caráter sagrado do poder. Com os jornais, os governantes podiam divulgar a própria imagem para aqueles que antes não teriam acesso a ela, por outro lado, seus opositores poderiam fazer circular imagens dos governantes que não condiziam com o que estes diziam dele. 


\section{DISERTACIONES}

ENSAYOS

Tecnologias y métodos computacionales para la investigación en ciencias sociales y comunicación

ISSN: 1856-9536

Doi: https://doi.org/10.12804/revistas.urosario.edu.co/disertaciones/a.8555

Volumen 14, Número 1 / Enero-junio 2021

Versión PDF para imprimir desde

http://revistas.urosario.edu.co/index.php/disertaciones

Com a televisão, o público pode realmente ver seus líderes, causando o aumento da importância da aparência (vestimenta, apresentação, modo como se portar). Ademais, com as sociedades democráticas e, conseguintemente, a escolha de novos líderes de tempos em tempos, os governantes não têm escolha "senão a de se submeterem à lei da visibilidade compulsória" (Thompson, 2013, p. 124).

Meyrowitz (1985) observa que essa nova realidade afetou a forma como percebemos as nossas lideranças. Antes das mídias eletrônicas, quando público e privado eram esferas totalmente distintas, os políticos conseguiam manter uma imagem que beirava a de um deus. Tal fato não foi mais possível com a evolução tecnológica, sobretudo com a chegada da televisão. Entre as décadas 1960 e 1980 houve a percepção de que não havia bons líderes no cenário político estadunidense, mas o autor levanta a hipótese de que, nesse período, o que ocorreu não foi a total ausência de lideranças e sim a incapacidade de adaptação dos políticos da época à ausência de bastidores. De acordo com Meyrowitz (1985), as barreiras entre público e privado se tornaram tão tênues que beiravam a inexistência. Tudo estava sujeito a ser exposto pela mídia. A obrigatoriedade de exposição midiática também é percebida por Rodrigues (1990), que afirma que a realidade é determinada pela mídia, ou seja, tudo que não é abordado por ela não tem existência reconhecida pela sociedade.

Braga $(2006,2011)$ acredita que alguns pesquisadores atribuem aos produtos midiáticos muito mais poder do que de fato possuem. Isso porque não apenas a relação da mídia com os demais campos sociais se alterou, mas também houve mudanças na própria mediação. Atualmente, as práticas interacionais não estão restritas à mídia de massas. Entende-se, agora, o receptor como um sujeito que também é ativo no processo comunicacional. Braga (2012) ressalta que "o surgimento das novas tecnologias crescentemente disponibiliza possibilidades de midiatização para setores "não-midiáticos” (p. 36). Cria-se, assim, um fluxo contínuo de comunicação, no qual as mensagens são criadas com o foco nas respostas esperadas ou pretendidas. Pode-se dizer que a midiatização nada mais é do que tornar algo parte do discurso midiático.

Hjarvard (2012) lembra que o termo midiatização foi aplicado primeiramente ao impacto dos meios de comunicação na comunicação política. Uma forma dessa adaptação da política à lógica da mídia, para ele, é quando os políticos formulam suas declarações públicas em termos que personalizam e polarizam as questões, para que as mensagens tenham mais chances de serem veiculadas pela mídia. Fausto Neto (2012) exemplifica uma estratégia de midiatização por meio de uma análise da atuação do Instituto Lula no período da descoberta e tratamento do câncer do ex-presidente. Conforme explica, as duas operações feitas pelo Instituto Lula -antecipar a existência da doença e os efeitos sobre o corpo de Lula do tratamento quimioterápico- foram uma importante estratégia de midiatização ao se adiantar e evitar que o campo jornalístico fosse o enunciador e principal mediador da enfermidade do ex-presidente. $O$ Instituto Lula apresentou os fatos a partir dos enquadramentos que considerava mais importantes para Lula, sem poder de interferência das mídias noticiosas. Braga (2011) afirma que, ao criar novos circuitos informativos e comunicacionais, o processo de midiatização coloca em xeque, de certa forma, o poder dos campos simbólicos instituídos. Quebram a sua hierarquia e ignoram suas formas de funcionamento. Como se trata de um processo que se intensificou nos últimos anos, o autor é cauteloso em afirmar até que ponto isso, de fato, coloca em risco o poder de tais campos, ressaltando que é um período de transição, de mudanças também na lógica de como os sujeitos atuam na esfera pública. 


\section{DISERTACIONES}

ENSAYOS

Tecnologias y métodos computacionales para la investigación en ciencias sociales y comunicación

ISSN: 1856-9536

Doi: https://doi.org/10.12804/revistas.urosario.edu.co/disertaciones/a.8555

Volumen 14, Número 1 / Enero-junio 2021

Versión PDF para imprimir desde

http://revistas.urosario.edu.co/index.php/disertaciones

\section{O funcionamento do jornalismo e sua importância na construção da opinião pública}

Dentre as áreas mais impactadas por essas transformações está o jornalismo. Desde o século xx que pesquisadores percebem a influência da imprensa na sociedade. Teóricos como McCombs e Shaw acreditavam num agendamento feito pela mídia sobre os temas que seriam tratados na sociedade (Barros Filho \& Praça, 2014).

Para Noelle-Neumann (como citado em Barros Filho \& Praça, 2014), os temas não abordados cairiam no que ela chama de espiral do silêncio. Isso aconteceria porque, para a autora, as pessoas evitam agir e se expressar de forma contrária ao padrão dominante na sociedade para que não sejam isoladas. Assim, quanto mais uma opinião for considerada ilegítima, menos ela será pronunciada. Isso se agrava tendo em vista a consonância entre os meios de comunicação.

Esse fenômeno pode ser explicado de várias formas. Teóricos da perspectiva construcionista nos fazem lembrar, como escreve Traquina (2001), que esses processos são intrinsicamente ligados à nossa sociedade. 0 autor explica que são duas as vertentes dessa teoria: a estruturalista e a etnoconstrucionista. Ambas acreditam que as notícias são construídas pelos processos entre agentes sociais. Traquina explica que, para Stuart Hall e outros dos grandes teóricos da vertente estruturalista, os meios de comunicação não apenas relatam o que está acontecendo, como também oferecem maneiras de interpretar esses fatos. Porém, ao contrário do que alegam outras teorias, a mídia não se limitaria aos definidores primários da notícia. Esse papel caberia às fontes oficiais, as acreditadas, ou seja, a mídia apenas reproduz posições daqueles que estão no comando da sociedade. Esse determinismo de que os definidores primários estão no comando das ações é um dos pontos criticados dessa vertente.

Ainda que seja muito influenciada por poderes externos, a imprensa tenta parecer ser imparcial e objetiva, como explica Tuchman (1996). Dentre os pontos citados por ela estão a apresentação da possibilidade de conflito, que acontece quando o jornalista entrevista várias pessoas sobre um determinado assunto. Quando os entrevistados têm visões coincidentes sobre o tema, é gerada uma ideia de verdade sobre o que foi dito. Pode-se ainda somar provas auxiliares, ou seja, documentos e dados que possam ratificar o que foi dito pelos entrevistados. Mesmo citações podem ser usadas de forma judiciosa, como explica Tuchman (1996). Para não fazer uma afirmação, o jornalista pode usar em seu texto a fala de outra pessoa. Mesmo que outros elementos do texto possam questionar o que foi dito, outra estratégia pode ser empregada para que o leitor tenha a impressão de que uma opinião é mais relevante que a outra: a organização do texto. A escrita jornalista, como lembra a autora, é feita no formato de pirâmide invertida, no qual as informações mais relevantes são dadas primeiro e as menos importantes são deixadas para o fim do texto.

É devido à credibilidade mantida pela imprensa que os políticos tentam se enquadrar em seus critérios de noticiabilidade para se introduzir na mídia. Sabendo da preferência do jornalismo pelo extraordinário, a política organiza os fatos para que se transformem em espetáculo. Essas estratégias fazem com que, segundo o autor, existam cada vez menos notícias espontâneas do mundo da política, fatos que não tenham sido pré-fabricados para atrair o olhar dos noticiários.

Contudo, a web, como explica Fausto Neto (2012), tornou a circulação de informações muito mais fácil e reduziu a distância entre emissores e receptores, intensificando o processo de midiatização. Isso porque, com a internet, 


\section{DISERTACIONES}

ENSAYOS

o emissor pode enviar uma mensagem em tempo real para um grande número de pessoas, sendo tanto mídia quanto público para mensagens, processo chamado por Castells (2017) de autocomunicação em massa. Para o autor, a autocomunicação em massa surge dessas mudanças dos meios tradicionais de comunicação somadas às novas possibilidades da comunicação interpessoal trazidas pela Web 2.0 e 3.0. Os produtos nativos da internet, como escreve Castells (2017), tendem a ser multimodais e a oferecer incontáveis possibilidades, formando redes horizontais de comunicação.

Porém, como afirma Recuero (2014), nem todas as pessoas ou grupos têm a mesma influência na internet e a qualidade das conexões varia conforme o capital social dos autores. Recuero (2014) entende capital social como um conjunto de recursos definidos pelo conteúdo da comunicação que estão presentes nas relações sociais que podem ser usados individualmente ou em grupo. Pode-se dizer, portanto, que aqueles que se comunicam por interações reativas têm mais capital social e são mais ouvidos, uma vez que sua comunicação é centralizada e suas conexões não perdem força com o tempo.

Castells (2017) não descarta que alguns têm mais poder que outros na internet. 0 autor registra que as grandes empresas de comunicação também estão migrando para o meio on-line. Assim, redes verticais e horizontais se encontram na web. Uma das razões para isso é o caráter comercial da mídia e sua dependência da publicidade. Além de ser impossível ignorar que a infraestrutura da rede pertença à corporações. Os sites mais acessados como o Google, o YouTube e o Facebook pertencem à empresas privadas.

De acordo com Moraes (2013), a capacidade de apropriação de diferentes lexos é uma das principais características do sistema midiático atual, juntamente com a habilidade de influir na opinião pública, podendo endossar ideologias, sendo uma delas a sustentação de modelos consumistas e individualistas na sociedade. Essas características foram acentuadas com a mídia digital. Uma estratégia usada pela mídia para influenciar na opinião pública é o enquadramento noticioso. Porto (2002) explica que alguns caracterizam essa teoria como um complemento à do agendamento ou agenda setting. Se os teóricos do agenda setting, McCombs e Shaw, diziam que a mídia determinava sobre o que o público deveria pensar, o enquadramento funcionaria como um segundo nível disso, ao dizer que a mídia poderia influenciar em como as pessoas pensam (Porto, 2002).

Contudo, não existe um consenso quanto à definição de enquadramento. Porto (2002) cita a perspectiva de Goffman, na qual "enquadramentos são entendidos como marcos interpretativos mais gerais construídos socialmente que permitem às pessoas fazer sentido dos eventos e das situações sociais” (p. 4). Porém, segundo ele, a definição mais utilizada é a de Gitlin, na qual "enquadramentos são entendidos como recursos que organizam o discurso através de práticas específicas (seleção, ênfase, exclusão etc.) e que acabam por construir uma determinada interpretação dos fatos" (Porto, 2002, p. 6). Ambas deixam claro uma coisa: enquadramentos são ferramentas de poder. Mesmo que dois textos tratem de fatos idênticos, a maneira de abordar pode mudar a forma como as pessoas o compreendem. Por essa razão, existem várias formas de se estudar os enquadramentos no jornalismo. Essas delimitações vão variar conforme o tipo de texto analisado e o contexto em que se inserem. Nesse artigo, determinamos duas categorias de enquadramento: segundo à lógica do acontecimento e à lógica do desacontecimento. 


\section{DISERTACIONES}

ENSAYOS

\section{Acontecimento versus desacontecimento}

O jornalismo tradicional tem como componente mais relevante o acontecimento. Rodrigues (1990) explica que o acontecimento seria um ponto inicial da significação. Visto como o real, ele existe de forma independente de opiniões, por isso é usado no discurso jornalístico. Na concepção de Rodrigues (1990), o acontecimento interrompe o cotidiano. Quanto mais improvável e distante da vida ordinária, maiores as chances de ir parar nos jornais. 0 autor explica que alguns fatores podem fazer com que um fato se distancie dos outros e se torne um acontecimento jornalístico. O mais comum deles é o excesso, uma afloração de um desvio à norma feita ou por indivíduos ou por instituições. Outro fator apontado é a falha, caracterizada pela insuficiência ou defeito dos corpos. $O$ terceiro elemento é a inversão, quando a rotina é invertida.

A busca do jornalista pelo distanciamento da realidade pode ter influenciado num fenômeno observado por Boorstin (2020). Segundo o autor, ao ler notícias desinteressantes as pessoas já não dizem: "como o mundo está chato", dizem "como o jornal" está chato. Para Boorstin, comentários como esse demonstram que no século xx o jornalista não é mais entendido apenas como aquele responsável por contar aquilo que aconteceu. Pois, se o jornalista apenas reporta, o que ele poderia fazer se os acontecimentos estão ou não entediantes? De acordo com Boorstin, essa busca incessante pelo extraordinário faz com que apenas os fatos não sejam suficientes para atender às expectativas do receptor pela quebra de sua rotina. Tem-se então a ideia de fabricar-se fatos, chamados por ele de "pseudo-events", ou pseudo-acontecimentos, em uma tradução nossa. Se nada novo acontece pode-se inaugurar um lustre em um hotel e inventar um motivo qualquer para que isso se torne relevante.

Uma lógica contrária é usada por Eliane Brum no cunho do termo desacontecimento. A palavra é empregada pela jornalista para descrever a temática de seus trabalhos. Para ela, buscá-lo é descobrir o extraordinário no comum. São situações que acontecem todos os dias, que não vão parar nos jornais, mas que não deixam de ser importantes.

O olhar que enxerga o invisível é, segundo Brum (2008), mediado por amor e compaixão pelo outro. Sendo assim, escrever sobre o desacontecimento torna necessário o uso de novas estratégias. Preocupada em mostrar o máximo da realidade, o texto de Eliane Brum é rico em detalhes, para que os leitores possam tomar suas próprias conclusões e fazer suas próprias escolhas. Ela busca pelo complicado, pois, segundo Brum (2008), o fácil é óbvio e, por essa razão, já foi contado antes.

Ainda que Elaine Brum faça um trabalho rigoroso de apuração, detalhando tudo que viu e ouviu, e ainda reproduza a fala de seus personagens da mesma maneira como foram ditas, a jornalista reconhece que não é imparcial. Para ela, ideais de objetividade e isenção jamais poderão ser atingidos, e essa incapacidade deve ficar clara.

Para Vivar e Abib (2018), Brum criou um novo gênero jornalístico: o jornalismo do desacontecimento, caracterizado por uma visão complexa, que não busca respostas fáceis e sim o aprofundamento de todas as questões tratadas no texto. Esse pensamento complexo, segundo os autores, faz com que a jornalista leve seus debates para outras áreas, diferenciando-se dos demais ao problematizar questões e ampliar horizontes. Os autores afirmam que esse estilo pode estar presente tanto nas reportagens quanto nas colunas de opinião, que passam a ser espaços de experimentação, misturando diversos estilos e trazendo humanidade aos relatos. 


\section{DISERTACIONES}

ENSAYOS

\section{A tradição literária do jornalismo}

Contudo, a humanização dos relatos não é uma característica exclusiva do jornalismo do desacontecimento. Na verdade, este é um dos principais atributos do jornalismo literário, como escreve Lima (2009). Embora a princípio jornalismo e literatura pareçam ser áreas distantes, em suas origens, o jornalismo era considerado um ramo literário.

Habermas (1984) chamou de "imprensa político-literária" o jornalismo que foi feito durante os séculos xvilI e xIx. Isso porque, como explica Bulhões (2007), na França do século xIx, a imprensa era fortemente ligada ao debate político, privilegiando-se a doutrinação e a opinião. Ademais, essa também foi a época em que os folhetins estavam no auge de sua popularidade, representando um fenômeno das massas.

No entanto, tais características alteraram-se com a chegada, no fim do século xixe início do século $\mathrm{xx}$, do modelo norte-americano, para o qual o jornalismo deve pautar-se pela objetividade e pela lógica do mercado, assumindo o discurso do jornalismo como o retrato da realidade tal qual ela é. "Para atingir esses objetivos, os jornalistas passaram a usar uma metodologia padronizada que envolvia ouvir e citar fontes, dispor informações por ordem de importância e responder no primeiro parágrafo seis perguntas sobre o fato: O quê? Quem? Quando? Onde? Como? Por quê?" (Bulhões, 2007, p. 23).

Habermas (1984), ao discutir as transformações da esfera pública burguesa frente ao poder do capitalismo e da indústria cultural, afirma que a imprensa passou por três fases, partindo da imprensa artesanal (no século xıx quando os jornais eram artesanais e restritos a um pequeno público), chegando à imprensa político-literária (quando a burguesia trava o poder com a aristocracia e os veículos noticiosos funcionam como canais de divulgações dos ideais políticos, resultado de discussões públicas nos cafés e salões do século xviII), até culminar na grande imprensa capitalista no século xx, quando se adota o modelo norte-americano e o jornal se torna uma mera mercadoria a serviço do capitalismo tardio.

Ainda assim, a literatura nunca esteve totalmente apartada dos jornais. Martinez (2017) diz que são muitos os nomes dados ao gênero que une jornalismo e literatura, mas talvez o mais preciso, devido à sua característica narrativa seja Jornalismo Literário. Para a autora, mais do que englobar técnicas do jornalismo e da literatura, essa modalidade exige que o profissional tenha conhecimentos de outros campos, como a História, a Sociologia, a Psicologia e a Antropologia. Por essa razão e pelo fato de exigir uma sensibilidade apurada, que estabeleça uma relação emocional entre leitor e texto, a autora acredita que o Jornalismo Literário seja uma modalidade para poucos

Segundo Pena (2013), o Jornalismo Literário volta às raízes do jornalismo diário, utiliza de seus saberes e técnicas para criar um jornalismo mais profundo. Ainda é crucial a apuração rigorosa dos fatos, somada à observação atenta. Para Lima (2009), além de precisão e exatidão, o Jornalismo Literário precisa seguir um estilo próprio e autoral, fazendo uso da criatividade e do simbolismo para contar uma história humanizada e universal. Para isso é preciso ter responsabilidade ética e ter uma visão compreensiva da realidade.

Pena (2013) explica que os relatos presentes nos textos devem transcender o cotidiano. 0 jornalismo incorpora a perenidade da literatura. O fato não precisa ser uma novidade. No Jornalismo Literário importa que o texto proporcione ao leitor uma visão ampla da realidade. Para isso, a contextualização deve ser a mais abrangente possível. $\mathrm{O}$ autor deve relacionar as informações, compará-las, mostrá-las sobre outras perspectivas. Entre os 


\section{DISERTACIONES}

ENSAYOS

critérios de noticiabilidade do jornalismo literário está, em primeiro lugar, a cidadania. Os temas escolhidos devem contribuir para a formação do leitor como um cidadão e trabalhar para o bem comum.

Por essas razões, o Jornalismo Literário é mais comum em reportagens que, como explica Lima (2009), contrapõem-se às notícias por conseguirem contextualizar os acontecimentos e estabelecer relações entre eles. A reportagem inaugura um novo tipo de jornalismo, o interpretativo, que "busca não deixar a audiência desprovida de meios para compreender o seu tempo, as causas e as origens dos fenômenos que presencia e as consequências para o futuro" (Lima, 2009, p. 19).

Aron (2012) concorda que as reportagens são espaços importantes para o desenvolvimento de um jornalismo com características literárias. Para ele, como também apontado por Pena (2013), esse tipo de jornalismo está ligado às causas sociais. Por esta razão, Aron classifica esse gênero como reportagem social. Além das características literárias, esse tipo de reportagem, que se popularizou na França no período entreguerras, diferencia-se por não ser escrita nem por estudiosos nem por literatos, e sim por jornalistas, chamados por ele de repórteres sociais.

Comme le grand reporter, le reporter social organise la mise en scêne d'une découverte dont il est le témoin privilégié. San récit est généralement écrit à la premiêre personne du singulier. II traduit les réactions sensibles d'un sujet découvrant avec des émotions qu'il veut partager une situation méconnue ou occultée. [...] A l'instar du reportage en général, le reportage social se caractérise aussi par le lien complexe qu'il construit entre sa vocation documentaire et l'usage conscient des moyens de la littérature (Aron, 2012, p.10). ${ }^{1}$

No caso do Brasil, a primeira experiência com a maneira "moderna" de se fazer jornalismo é creditada pelo historiador Brito Broca à João do Rio, pseudônimo de Paulo Barreto. Para o historiador, João do Rio foi o primeiro cronista a sair do ambiente da redação para apurar os fatos na rua, transformando a crônica em reportagem. Os textos de João do Rio eram marcados pelo seu olhar humanizado. No início do século xx, a cidade do Rio de Janeiro passava por muitas transformações. A modernização fez com que os pobres fossem "empurrados" para os morros, que se tornaram as favelas atuais. Rozendo e Mega (2014) contam que João do Rio via os excluídos de maneira diferenciada, expondo seus sentimentos e pontos de vista, bem à maneira que Gay Talese faria décadas mais tarde.

Bulhões (2007), porém, aponta que João do Rio não era um repórter, mas sim um jornalista-flâneur, ou seja, um curioso que caminha pelas ruas querendo ser íntimo do fato, sem ter compromisso com o tempo. "Um repórter de uma época de ajustes e adaptações, sem que a atitude do profissional do jornalismo conviva com o diletantismo e a indeterminação" (Bulhões, 2007, p. 110).

1 "Como o grande repórter, o repórter social organiza a exibição de uma descoberta da qual é testemunha privilegiada. A narrativa é geralmente escrita na primeira pessoa do singular. Traduz as reações sensíveis de um sujeito descobridor com emoções que ele deseja compartilhar em uma situação desconhecida ou oculta. [...] Como o jornalismo em geral, o jornalismo social também se caracteriza pelo vínculo complexo que constrói entre sua vocação documental e o uso consciente dos recursos literários". Tradução nossa. 


\section{DISERTACIONES}

ENSAYOS

Bulhões (2007) também afirma que os folhetins, nesse período, começaram a perder sua força. Agora, eram os fait-divers que ganhavam espaço. Os fait-divers são o tipo de reportagem que abordam a vida de forma extravagante e extraordinária. No início do século xx, essa maneira de se fazer jornalismo ganhou espaço e consolidou a imagem do repórter como um aventureiro. A verdade é que a ficcionalidade não deixava de estar presente.

Contudo, os fait-divers não eram a única forma de intercepção entre a reportagem e a literatura. Exemplo disso é o livro "Os Sertões", de Euclides da Cunha, apontado por Martinez (2017) como central para o desenvolvimento do Jornalismo Literário no Brasil. Lançado como livro em 1903, a obra inicialmente foi divulgada como uma série de reportagens sobre a última expedição da Guerra de Canudos, ocorrida no fim do século xix. $\mathrm{O}$ autor usou de artifícios literários associados à apuração jornalística para retratar a terra, a pessoa do sertanejo e a luta. O livro, originário dos jornais, se tornou um clássico da literatura pré-modernista.

Contudo, como explica Bulhões (2007), os anos 1950 foram marcados por um jornalismo distante das letras. Essa mudança derivou do crescimento dos meios de comunicação como empresas de produção industrializada. Foi nesse mesmo período que jornais e revistas sofreram uma ampla mudança na diagramação e passaram a abrigar fotografias em suas páginas.

Mesmo durante esse período, a literatura não esteve totalmente ausente do jornalismo, mas ela foi restrita a figurões como Nelson Rodrigues. As reportagens, geralmente, tidas como espaço de mais liberdade, eram tolhidas pela padronização jornalística. A resistência não chegou a ser efetiva até a chegada da revista Realidade em 1966. Em plena época de censura imposta pela Ditadura Militar, a Realidade foi capaz, em extensas e bem escritas reportagens, de abordar temas considerados tabus de forma inovadora, influenciando muito o comportamento atual, como o divórcio e a liberdade sexual. Outro diferencial da Realidade era seu público leitor, que congregava homens, mulheres e jovens, que precisavam reservar a revista na banca, pois os primeiros exemplares sempre se esgotavam logo. Nos primeiros quatro meses, a venda nas bancas subiu de 250 mil exemplares para 450 mil (Marão, 2010a, 2010b).

\section{A trajetória de Eliane Brum}

Eliane Brum é uma das mais reconhecidas jornalistas brasileiras, com textos publicados em veículos nacionais e internacionais. Por 11 anos, trabalhou no jornal gaúcho Zero Hora, para o qual escreveu os textos que deram origem, mais tarde, ao livro A Vida Que Ninguém Vê.

Durante 10 anos, Eliane foi repórter da Revista Época, em São Paulo. A partir de 2010, ela passou a atuar como freelancer e, desde 2013, assina uma coluna quinzenal no site do jornal El País. Ao longo de sua carreira, escreveu seis livros, sendo cinco deles de não ficção. Como jornalista, recebeu mais de 40 prêmios.

Com um olhar que enxerga o invisível aos olhos comuns, Brum fez reportagens que dão lugar de notícia a temas que seriam ignorados pelos noticiários, chamados por ela de desacontecimentos. "O que esse olhar desvela é que o ordinário da vida é o extraordinário. E o que a rotina faz com a gente é encobrir a verdade, fazendo com que o milagre do que cada vida é se torne banal. [...] cada Zé é um Ulisses. E cada vida uma Odisseia" (Brum, 2006, p. 187). 


\section{DISERTACIONES}

ENSAYOS

Tecnologias y métodos computacionales para la investigación en ciencias sociales y comunicación

ISSN: 1856-9536

Doi: https://doi.org/10.12804/revistas.urosario.edu.co/disertaciones/a.8555

Volumen 14, Número 1 / Enero-junio 2021

Versión PDF para imprimir desde

http://revistas.urosario.edu.co/index.php/disertaciones

Rozendo e Mega (2014) comparam o olhar da jornalista ao de João do Rio. Para os autores, os dois funcionariam de maneira complementar. Ele fazendo um "diagnóstico" da miséria e ela trazendo a esperança de que um dia todos serão vistos como iguais. Ambos com o olhar voltado àqueles que não têm espaço nos noticiários e reportando suas realidades de maneira distinta da que é vista nos jornais diários. "Eles não se prendem à objetividade e à imparcialidade jornalística, tanto que muitas de suas narrativas são escritas em primeira pessoa. Além disso, possuem formas de relato que humanizam os personagens ao expor seus sentimentos, medos e aflições; enxergando-os como protagonistas e não como coisas" (Rozendo \& Mega, 2014, p. 14).

Mais inovador ainda é falar do outro usando o "eu". Fonseca (2013) explica que Eliane Brum, em suas reportagens, quebrou as barreiras impostas pelo Positivismo ao jornalismo. Eliane Brum não esconde sua parcialidade. A autora observa que a jornalista, muitas vezes, utiliza a primeira pessoa, dando voz ao outro por meio de seu olhar. Ela é apenas uma testemunha que dá o depoimento do que aconteceu com o outro.

Contudo, Brum não trabalha mais com o estilo que a tornou reconhecida. Tendo migrado para a internet, onde reina o imediatismo (Breadshaw, 2014) e tem pouco espaço para detalhamento e contextualização dos fatos, de que forma a jornalista emprega suas estratégias de destaque ao desacontecimento, ou seja, de acontecimentos cotidianos e aos cidadãos comuns? Seria possível para ela, dentro de um tema tipicamente noticioso, como é a eleição de um presidente da república, introduzir a lógica do desacontecimento? E se sim, como?

\section{Análise dos textos}

Para responder às perguntas propostas, foi feita uma Análise de conteúdo segundo Bardin (2011). Essa metodologia envolve uma pesquisa quantitativa e/ou qualitativa na qual são determinadas categorias de análise. Foram selecionados como objetos "A revanche dos ressentidos" (06/11/18) e "Cem dias sob o domínio dos perversos" (12/04/2019), duas colunas publicadas por Eliane Brum no site do jornal global El País. Para analisá-las, foram determinadas as seguintes categorias: 1 ) as imagens dos personagens construídas pela jornalista; 2 ) a relação entre acontecimento e desacontecimento presente no texto; 3) o enquadramento escolhido por Brum em ambas as situações. Neste trabalho optou-se por priorizar o caráter qualitativo da análise de conteúdo proposta por Bardin (2011).

\section{A Revanche}

A coluna de Eliane Brum para o El País "A revanche dos ressentidos" foi publicada no dia 6 de novembro de 2018. Uma particularidade do texto é o seu tamanho. Enquanto os textos publicados por Eliane Brum em 2019 têm, em média, 40 parágrafos, o da eleição de Jair Bolsonaro conta com apenas sete, sendo que o último deles tem somente duas linhas. Essas características são estranhas aos textos de Brum. A jornalista costuma se alongar tanto em suas reportagens quanto em suas colunas. Ela aponta, inclusive, que uma das vantagens de escrever para a internet é que na web não há limite para suas palavras.

Embora se trate de uma coluna sobre o resultado da eleição, o único político mencionado no texto é o presidente eleito. $\mathrm{O}$ foco não são projetos que deveriam ou não ser adotados para esta ou aquela área. Nenhuma discussão típica da política ou democracia é levantada. Na verdade, Brum não parece acreditar que o Brasil seguirá para um 


\section{DISERTACIONES}

ENSAYOS

futuro democrático. A jornalista compara o Brasil de 2018 com a realidade de um regime autoritário como a do livro 1984, de George Orwell, na qual guerra, escravidão e ignorância são vistas como paz, liberdade e força.

Brum descreve um Brasil cuja atmosfera é "tóxica", um lugar onde gays, negros, mulheres e qualquer pessoa que pense diferente dos eleitores de Jair Bolsonaro são inimigos e estão sob ameaça. Para demonstrar isso, ela emprega recursos da literatura, como em seu primeiro parágrafo.

Eu acompanhava uma amiga no aeroporto, em São Paulo. Os elevadores que levavam do estacionamento aos terminais demoraram. Quando finalmente entramos, estava lotado. Um homem com um bebê no colo, possivelmente seu neto, gritou: “Quando Bolsonaro assumir, isso aqui vai andar rápido!”. E acrescentou “Pá! Pá! Pá!". Abri a boca para perguntar: "Você está atirando no seu neto?”. E então percebi que não poderia fazer isso sem me arriscar a sofrer violência. 0 homem e a família que o rodeava realmente pareciam acreditar que Bolsonaro dará "um jeito em tudo", dos "comunistas" que supõem existirem aos milhões, à velocidade dos elevadores (Brum, 2018, p. 1).

Eliane Brum descreve a eleição de Jair Bolsonaro como um acontecimento, que mudou o cotidiano das pessoas, fazendo com que do "esgoto do inconsciente" todo o tipo de "recalque" e "ressentimento" viesse à tona. Fatos que eram tidos como anormais, ou, pelo menos, não aceitos publicamente, como o espancamento de homossexuais, xingamentos a negros e ameaças a pessoas apenas pela cor da roupa que usam, passam a ser rotineiros. Ou seja, o politicamente correto deixou de ser uma regra civilizatória no Brasil, colocando em xeque os comportamentos, principalmente, que zelavam pelo respeito ao Outro e pela defesa dos direitos humanos.

Se antes esses eventos poderiam aparecer no jornal por serem acontecimentos, passam a ser ignorados por serem desacontecimentos, ou seja, normais. Essa transformação do que deveria ser extraordinário em ordinário é o que move o texto de Eliane Brum. Assim, ela volta-se para o novo cotidiano, no qual velhos amigos se separam por um deles querer a morte do outro e de sua família de comunistas, no que mães são recriminadas pela "indecência" de amamentarem em público, no que pessoas que achavam merecer mais sucesso vociferam "seu ódio contra quase todos", e no que aquele que "sempre se sentiu ofendido pela inteligência alheia, sente-se autorizado a exibir sua ignorância como se fosse qualidade” (Brum, 2018).

O esvaziamento das palavras, a transformação do anormal em rotineiro, a impossibilidade de comunicação sem ofensa, a intolerância do que seja minimamente diferente são pistas de que: "O pacto civilizatório, aquele que permitia a convivência, já vinha sendo rompido nos últimos anos no país. Agora foi rasgado por completo. Este é o primeiro sinal” (Brum, 2018, p. 1). Assim, a jornalista conclui seu texto, até então focado no cotidiano, em um anúncio: o Brasil está em guerra.

A escritora aciona, mesmo num texto curto, características típicas do Jornalismo Literário, que é o tom crítico em relação ao governo eleito. Como Habermas (1984) esclarece, uma das características do jornalismo político-literário era justamente o tom opinativo. Pena (2013), por sua vez, esclarece que, no Jornalismo Literário, o texto deve proporcionar uma visão mais ampla da realidade e deve ter entre os critérios de noticiabilidade a cidadania. Numa abordagem bem pessimista, a jornalista é sucinta ao não conseguir vislumbrar boas perspectivas para o país com a eleição de um presidente de direita que colocaria em prática uma pauta conservadora tanto de mercado como de costumes. 


\section{DISERTACIONES}

ENSAYOS

\section{O domínio dos perversos}

Em "Cem dias sob o domínio dos perversos", Eliane Brum adota um tom distante da narrativa de um texto literário. Embora o primeiro parágrafo da coluna não possa ser associado a um lead por não responder às perguntas centrais do texto, a autora aproxima-se mais de uma narrativa jornalística tradicional ao abordar no primeiro parágrafo fatos, acompanhados de hiperlinks, que indicam que os cem dias iniciais do governo de Bolsonaro foram marcados pela violência.

No primeiro dos três tópicos que se seguem, "A Perversão", Brum discute como Bolsonaro, mencionado nesse texto por 49 vezes ao longo dos 58 parágrafos, tomou conta de todas as esferas sociais. Segundo a jornalista, as ações do presidente, seus filhos e aliados é tópico das conversas cotidianas e, mais que isso, ele tomou o lugar da oposição. Como exemplo dessa situação, Brum aponta o comportamento do presidente com relação à reforma da previdência, dizendo que não a achava necessária nem gostaria de fazê-la. Devido a esse discurso, como aponta a jornalista, as propostas de outros partidos ficam ofuscadas.

Nem mesmo as alas dissonantes entre seus aliados têm espaço. Como lembra Brum, para evitar o aumento de popularidade do vice-presidente e da ala militar de seu governo, Bolsonaro resolveu relembrar e celebrar a ditadura em 31 de março.

Bolsonaro promoveu a memória dos crimes da ditadura pelo avesso, negando-os e elogiando-os. Poucas vezes a violência do regime autoritário foi tão lembrada e descrita quanto neste 31 de março. Foi Bolsonaro quem menos deixou esquecer os mais de 400 opositores mortos e 8 mil indígenas assassinados, assim como as dezenas de milhares de civis torturados. Para manter os generais no cabresto, Bolsonaro os jogou na fogueira da opinião pública fingindo que os defendia (Brum, 2019, p. 2).

Brum escreve que esse movimento de Bolsonaro, além de fragilizar seus adversários, serviu como teste de força para as instituições democráticas que se provaram frágeis, na visão da jornalista, uma vez que apenas a Defensoria Pública da União agiu, entrando com uma ação judicial para impedir que se comemorasse o período ditatorial. A situação foi classificada por Eliane Brum como patética.

Esse controle do que é dito, que toma conta até mesmo da imprensa, é o que Elaine Brum classifica como perverso. Para a jornalista, tudo não passa de uma estratégia de Bolsonaro, chamado por ela de "antipresidente" justamente por criar uma falsa oposição a ele mesmo e, com isso, legitimar um discurso liberal que seria mais brando do que ele diz propor.

A oposição, assim como a maioria da população, foi condenada à reação, o que bloqueia qualquer possibilidade de ação. Se alguém sempre jogar a bola na sua direção, você sempre terá que rebater a bola. E quando pegar esta e liberar as mãos, outra bola é jogada. Assim, você vai estar sempre de mãos ocupadas, tentando não ser atingido. Todo o seu tempo e energia são gastos em rebater as bolas que jogam em você. Deste modo, você não consegue tomar nenhuma decisão ou fazer qualquer outro movimento. Também não consegue planejar sua vida ou construir um projeto. É uma comparação tosca, mas fácil de entender. É assim que o governo Bolsonaro tem usado o poder para controlar o conteúdo dos dias e impedir a disputa política legítima das ideias e projetos (Brum, 2019, p. 2).

O descrito por Brum nesta primeira parte do texto se assemelha ao que a teoria da Espiral do Silêncio defende. Para Noelle-Neumann (como citado em Barros Filho \& Praça, 2014), os temas não abordados cairiam no que ela 


\section{DISERTACIONES}

ENSAYOS

chama de espiral do silêncio. Isso aconteceria porque, para a autora, as pessoas evitam agir e se expressar de forma contrária ao padrão dominante na sociedade para que não sejam isoladas. Assim, quanto mais uma opinião for considerada ilegítima, menos ela será pronunciada. Isso se agrava tendo em vista a consonância entre os meios de comunicação. Eliane Brum faz uma denúncia de que a onipresença de Bolsonaro nas conversações está, na verdade, excluindo todos os outros discursos e relegando-os a uma espécie de não existência à medida que não circulam na mídia, que se dedica a falar sobre o presidente que faz oposição a si mesmo.

No segundo tópico de seu texto, intitulado "A Barbárie", Brum observa a incapacidade de ação dos opositores de Bolsonaro em se desvencilhar das pautas propostas por ele. Para a jornalista, os políticos de esquerda estão assumindo um discurso de ódio como o de Bolsonaro, atacando seus aliados e ele por questões de obscenidade ou por não falarem um português correto.

Compreender como o discurso de ódio vai se imiscuindo na mente de quem acredita estar se contrapondo ao ódio é eticamente obrigatório. Se o governo de Bolsonaro é também oposição e crítica ao próprio Governo, isso não significa que ele não tenha um projeto e que este projeto não esteja se impondo rapidamente ao país. Tem e está. Somos hoje um país muito pior do que fomos. E somos hoje um povo muito pior do que fomos. Parte do objetivo dos violentos e dos odiadores é normalizar a violência e o ódio pela repetição. 0 bolsonarismo tem conseguido realizar esse projeto com uma velocidade espantosa (Brum, 2019, p. 3).

Enquanto esses discursos considerados por Brum como irrelevantes tomam conta do debate público, fatos que deveriam ser noticiados passam pela espiral do silêncio. Somente até a primeira quinzena de abril, quando a jornalista escreveu sua coluna, oito moradores de rua foram queimados vivos, 11 dos 25 suspeitos de assaltos a bancos foram mortos por policiais e outras 64 pessoas foram mortas pela polícia de São Paulo no mês de março.

A segunda parte do texto é dedicada a denunciar a barbaridade dos brasileiros que não se importam com essas questões o suficiente para dar a elas mais destaques do que aos atos de "auto oposição" de Bolsonaro. "Se fôssemos um país decente de gente decente pararíamos diante da barbárie e exigiríamos justiça” (Brum, 2019, p. 3).

Por fim, na última parte do texto, denominada "A Resistência", Brum urge os brasileiros a agirem contra a barbárie e denuncia que o Brasil convive com características típicas de um sistema autoritário. Para fazê-lo Eliane Brum propõe que criemos um comum, uma vez que "os perversos" gostam de alterar os significados das palavras. O segundo passo seria se reunir em comunidades reais, tornando-se ativista.

O ativista é aquele que deixa o conforto do seu umbigo e do seu entorno protegido para exercer a solidariedade. Governos como o de Bolsonaro agem para que cada um veja o outro como inimigo, e por isso temem o ativismo. Os bolsonaristas se alimentam da guerra porque a guerra separa as pessoas e faz com que elas não tenham tempo para criar futuro. A solidariedade é um gesto temido pelos autoritários. Por que você não está em casa lustrando o seu umbigo, é o que gostariam de perguntar? Ao corromper as palavras, é também esse o objetivo. Condenar cada um à prisão do seu silêncio (ou do seu eco), incapaz de alcançar o outro pela falta de uma linguagem comum (Brum, 2019, p. 2).

A jornalista argumenta que Bolsonaro deseja mandar para fora todos aqueles que destoam de seu discurso neoliberal. Ela denuncia uma guerra em que a maioria dos mortos é negra e pobre. Para resistir é preciso, segundo Brum, ter união. É preciso também ter arte, que "tira as pessoas do lugar" (Brum, 2019, p. 2). Seus últimos conselhos são que nos juntemos no riso, pois a alegria é uma das principais armas contra o perverso e que os desobedeçamos, para que nossos dias voltem a nos pertencer. 


\section{DISERTACIONES}

ENSAYOS

No artigo de Eliane Brum, encontramos uma jornalista que está distante da escritora que buscava os anônimos para encontrar uma forma de dar visibilidade e voz para eles em seus textos. Aqui, a escritora assume um tom panfletário, típico dos textos da fase político-literária, que aponta Habermas (1984), de tomada de posição. Destoa, nesse sentido, do jornalismo tradicional que trabalha sob a suposta objetividade e imparcialidade. Brum denuncia as barbaridades e assume a posição do jornalismo como ator social e político que interfere na realidade social, próximo da perspectiva construcionista. A diferença em relação ao Jornalismo Literário diz respeito ao personagem, já que aqui o seu principal alvo é o presidente Jair Bolsonaro, citado 49 vezes.

\section{Considerações finais}

Após discorrermos sobre cada uma das colunas, é possível perceber que as duas possuem muitas diferenças. Enquanto a primeira pouco menciona o presidente eleito, a segunda cita seu nome 49 vezes. Se a primeira tem sete parágrafos, a segunda tem 58 . Entretanto, para além das questões estruturais, "A revanche dos ressentidos" possui interseções marcantes com a literatura, como é característico dos textos de Eliane Brum, além de narrar situações do cotidiano. Há pouco nele que lembre um texto jornalístico.

O mesmo não pode ser dito sobre "Cem dias sob o domínio dos perversos". Em vários momentos, quando Brum recorre a acontecimentos recentes para comprovar seus argumentos, ela usa da objetividade jornalística. Ademais, o restante do texto não se conecta com características narrativas da literatura em nenhum momento e pouco fala do cotidiano. Na verdade, "Cem dias sob o domínio do perverso" aproxima-se bastante do que é classificado como uma coluna jornalística, usando de uma linguagem objetiva para comprovar argumentações e opiniões do autor, abordando temas que estejam sendo discutidos naquele período (Melo, 1985).

Por outro lado, como é esperado do jornalismo literário, ambas as colunas são críticas ao momento vivido pelo país, contextualizando e relacionando os fatos e buscando despertar a cidadania. Nos textos, Brum menciona que o significado das palavras vem sendo alterados pelos que ela chama de "perversos". Também nas duas ocasiões ela ressalta que o país vive momentos que o aproximam de uma situação de guerra e autoritarismo.

Outro aspecto que une "A revanche dos ressentidos" e "Cem dias sob o domínio dos perversos" é a tentativa de Bolsonaro de dominar os discursos. Sem usar este termo, Brum relata que a estratégia de midiatização feita pelo presidente é bem sucedida. Ele cala a oposição na política, como é retratado na segunda coluna, e também o público comum, como acontece quando Brum decide não confrontar o homem que apontava a arma feita com as mãos para uma criança no aeroporto.

É interessante notar, porém, que, apesar de conseguir marcar sua presença no cotidiano do país e também no discurso midiático, Bolsonaro, como provam os textos críticos de Eliane Brum, não consegue controlar por completo sua imagem, como já previa Thompson (2013). Ao mesmo tempo essa influência mostra, como apontou Castells (2017) a relevância que a internet tem hoje na construção da opinião pública, uma vez que permite a autocomunicação em massa.

Pode ser que o imediatismo que, segundo Breadshaw (2014) é característico da internet, tenha influenciado na escolha de abordagem de Brum. A jornalista, em ambos os textos, traz temáticas que estariam mais ligadas ao âmbito do acontecimento do que do desacontecimento. Ainda assim, é possível dizer que a jornalista busca por 


\section{DISERTACIONES}

ENSAYOS

ângulos diferentes, como é típico do Jornalismo Literário, pois talvez a principal notícia que ambas as colunas trazem é o deslocamento de fatos que deveriam estar na esfera do extraordinário, como a violência, se transformando em fatos tão cotidianos que as pessoas passam a não se importar com a barbaridade de nossos tempos.

\section{Referências}

1. Aron, P. (2012). Entre journalisme et littérature, l'institution Du reportage. Contextes,11,2-11. https://doi. org/10.4000/contextes.5355

2. Bardin, L. (2011). Análise de conteúdo. Edições 70.

3. Barros Filho, C., \& Praça, S. (2014). Agenda setting, newsmaking e a espiral do silêncio. InA. Citelli, C. Berger, M. A. Bacegga, M. I. Vassalo, M. V. Françaet al.(Eds.), Dicionário de comunicação: escolas, teorias e autores (pp. 25-35). Contexto.

4. Boorstin, D. (2020). The image: a guide to pseudo events in America. http://www.columbia.edu/itc/journalism/ j6075/edit/boor.html

5. Braga, J. L. (2006). A sociedade enfrenta sua mídia: dispositivos sociais de crítica midiática. Paulus.

6. Braga, J. L. (2011). Constituição do campo da comunicação. Verso e Reverso, 25(48), 63-77. http://revistas. unisinos.br/index.php/versoereverso/article/view/924

7. Braga, J. L. (2012). Circuitos versus campos sociais. In M.A. Mattos, J. Janotti Jr., N. Jacks (Orgs.), Mediação \& midiatização (pp. 29-52). EdufBA.

8. Breadshaw, P. (2014). Instantaneidade:efeito da rede, jornalistas mobile, consumidores ligados e o impacto no consumo, produção e distribuição. In J. Canvilhas (Ed.), Webjornalismo: 7 caraterísticas que marcam a diferença(pp. 119-129).Livros LabCom.

9. Brum, E. (2006). A Vida que ninguém vê. Arquipélago.

10. Brum, E. (2008). O Olho da rua: uma repórter em busca da literatura da vida real. Globo.

11. Brum, E. (6 de novembro de 2018).A revanche dos ressentidos. El Pais. https://brasil.elpais.com/ brasil/2018/11/06/opinion/1541508597_737258

12. Brum, E. (10 de abril de 2019). Cem dias sob o domínio dos perversos. El Pais. https://brasil.elpais.com/ brasil/2019/04/10/opinion/1554907780_837463.html?fbclid=IwAR0qAKiZEgn7-gmd4okL4cVagNpqJsvEuBGCOh2fdOGUrXnmsco_y9H9dn4

13. Bulhões, M. (2007). Jornalismo e literatura em convergência. Editora Ática.

14. Castells, M. (2017). O poder da comunicação. Paz e Terra.

15. Fausto Neto, A. (2012). Contendas de sentidos: estratégias de midiatização da doença do ex-presidente Lula. Revista Interamericana de Comunicação Midiática, 11(22), 246-271. https://periodicos.ufsm.br/ animus/article/view/7018

16. Fonseca, I. de A. (2013). Guinada subjetiva no jornalismo: um olhar opaco em direção às narrativas da repórter Eliane Brum. Congresso Brasileiro de Ciências da Comunicação, Intercom Manaus.

17. Habermas, J. (1984). Mudança estrutural da esfera pública. Tempo Brasileiro.

18. Hjarvard, S. (2012). Midiatização: teorizando a mídia como agente de mudança social e cultural. Matrizes, 5(3), 53-91. https://doi.org/10.11606/issn.1982-8160.v5i2p53-91 


\section{DISERTACIONES}

ENSAYOS

19. Lima, V. A. de. (2004). As sete teses sobre mídia e política no Brasil. Revista USP, 61, 58-57. https://doi. org/10.11606/issn.2316-9036.v0i61p48-57

20. Maciel, A., Lavor, T., Roza, G., Ribeiro, A., Lázaro Jr., J., \& Zanatta, C. (10 de outubro de 2018). Apoiadores de Bolsonaro realizaram pelo menos 50 ataques em todo o país. Pública. https://apublica.org/2018/10/ apoiadores-de-bolsonaro-realizaram-pelo-menos-50-ataques-em-todo-o-pais/

21. Marão, J. C. (2010a). Por que falar de realidade? In J. C. Marão \& J. H. Ribeiro (Eds.), Realidade re-vista (pp. 17-20). Realejo Edições.

22. Marão, J. C. (2010b). Vida, paixão e morte de nossa senhora realidade. In J. C. Marão \& J. H. Ribeiro (Eds.), Realidade re-vista (pp. 21-37). Realejo Edições.

23. Martinez, M. (2017). Jornalismo literário: revisão conceitual, história e novas perspectivas. Intercom-RBCC, 40(3), 21-36. http://portcom.intercom.org.br/revistas/index.php/revistaintercom/article/view/2798/2103

24. Melo, J. M. de. (1985). A opinião no jornalismo brasileiro. Vozes.

25. Meyrowitz, J. (1985). No sense of place.The impact of electronic media on social behavior. Oxford University Press.

26. Moraes, D. de. (2013). Sistema midiático, mercantilização cultural e poder mundial. In D. de Moraes, I. Ramonet \& P. Serrano (Eds.), Mídia, poder e contrapoder: da concentração monopólica à democratização da informação(p. 183). Boitempo-FAPERJ.

27. Pena, F. (2013). Jornalismo literário. Contexto.

28. Porto, M. P. (2002). Enquadramentos da mídia e política. Encontro Anual da Associação Nacional de Pós-Graduação e Pesquisa em Ciências Sociais, Anpocs, Caxambu.

29. Recuero, R. (2014). Redes sociais na internet. Sulinas.

30. Rodrigues, A. D. (1990). Estratégias da comunicação: questão comunicacional e formas de sociabilidade. Editorial Presença.

31. Rozendo, S., \& Mega, V. M. (2014). A humanização dos relatos em João do Rio e Eliane Brum: observação e consonância que perpassam o tempo. Encontro Regional Sudeste de História da Mídia, Alcar, Rio de Janeiro.

32. Santos, W. G. (2017). Democracia impedida. Editora da FGv.

33. Souza, J. (2016). A radiografia do golpe: entenda como e por que você foi enganado.LeYa.

34. Thompson, J. (2013). A mídia e a modernidade: uma teoria social da mídia. Vozes.

35. Traquina, N. (2001). O estudo do jornalismo no século xx. Unisinos.

36. Tuchman, G. (1996). A objetividade como ritual estratégico: uma análise das noções de objectividade dos jornalistas. In N. Traquina (Org.), Jornalismo: questões, teorias e "estórias" (pp. 74-90). Vega Editora.

37. Vivar, J. M. F., \& Abib, T. A. (2018). O expediente da argumentação no jornalismo de Eliane Brum: análise de suas colunas ao El País Brasil. Comunicação \& Inovação, 19(40), 24-38. https://seer.uscs.edu.br/index.php/ revista_comunicacao_inovacao/article/view/5175/2471 